Годишњак Филозофског факултета у Новом Саду, Књига ХХХІХ-1 (2014)

Annual Review of the Faculty of Philosophy, Novi Sad, Volume XXXIX-1 (2014)

Дејан Пралица

Филозофски факултет Универзитета у Новом Саду

УДК 347.78:[654.191:316

$774(497.113)$

Оригиналан научни рад

\title{
ПИРАТСКЕ РАДИО-СТАНИЦЕ У СРБИЈИ
}

Циљ овог рада јесте да укаже на проблематику постојања пиратских радио-станица у Републици Србији, с акцентом на Аутономну Покрајину Војводину. Историјат пиратских електронских медија у Европи почиње половином 20. века, када су неке од нелегалних станица, између осталог, представљале авангарду тадашње радиодифузије и конкурецију због које су и офищијелне радио-станице морале да унапређују свој програм. Више од пола века касније, улога пиратских медија делимично је промењена. Такви медији представљају нелојалну конкуренцију радио-станицама које су уредно добиле фреквенције, а својим тривијалним програмских садржајима урушавају квалитет програма у легалном радијском етру. Иако је број медија који неовлашћено користе радиофреквенцијски спектар у константном опадању, они и даље представљају велики проблем. У раду ће бити речи и о томе на који начин овлашћена (државна) регулаторна тела утичу на смањење броја нелегалних емитера у радијском етру Србије.

Кључне речи: пиратерија, радиодифузија, радио-станица, ауторско право, РРА, РАТЕЛ.

„Као отворени медиј у сталном контакту са слушаоцима временом смо схватили шта је базични проблем Србије: необразованост, примитивизам, доминација искључивости, страха од другог и другачијег, нетолерантност и масовна неосвешћеност људи да су појединци, а не искључиво саставни део неког колектива, масе или гомиле. Зато је за многе слушаоце, као и оне који су самоослушкивали и прислушкивали наш програм, Радио 021 био цивилизацијски шок“" (Златковић 2001:6-7).

\section{1. УВОДНЕ НАПОМЕНЕ}

Медији имају врло важну улогу у функционисању демократског друштва. Њихова улога као чувара демократије веома је битна и у земљама у којима влада диктатура. „Медији имају улогу јавних контролора који својом делатношћу (...) формирају јавно мњење“ (Николић, 2010: 25). Међутим, све оштрија конкуренција и технолошки напредак довели су до тога да су медији почели међусобно да се угрожавају. Појава радио-пиратерије, у првој поло-

novisad1748@open.telekom.rs 
вини 20. века и под друачијим друштвено-политичким околностима него данас, за врло кратко време довела је до промена у програмима леганих емитера. Савремена пиратерија, односно пиратске станице 21. века, угрожавају легалне емитере до те мере да им је чак и опстанак доведен у питање.

\section{2. ЦИЉ РАДА И ДЕФИНИСАЬЕ ПРЕДМЕТА ИСТРАЖИВАњА}

Циљ овог рада јесте да укаже на проблематику о(п)станка пиратских радио-станица у Србији и њихов утицај на легалне емитере.

У раду ће најпре бити дат кратак преглед историјата настанка пиратских радија у Европи, као и утицај који су такве станице извршиле на легалне медије у етру. Након тога, детаљније ће бити речи о пиратским станицама у Србији, њиховом настанку, улози и разлозима вишегодишњег опстанку у радиодифузији, упркос покушајима регулаторних тела да их забране, као и реакцијама новинарских и медијских удружења против нелагалних емитера.

Предмет овог рада јесу пиратски медији, односно пиратске радио-станице или краће пирати. Дефиниције пиратских медија врло су сличне у различитим изворима. Према Речнику српскога језика пират је „онај који се нелегално, без дозволе бави каквом делатношћу (емитовањем радио-програма)“ (Речник српскога језика, 2007:929). Према The Australian Concise Oxford Dictionary пират је „особа или организација која емитује програм без званичног овлашћења. Особа која повређује ауторска или друга пословна права другог“ (Шинглер, Виринга, 2000:61). Према британском Dictionary of Media Studies ,пиратски радио јесте радио станица која илегално емитије програм (без дозволе), не плаћа таксе за фреквенције и ауторска права за пуштање музике, али може да привуче велики број слушалаца“ (Dictionary of Media Studies, 2006:176).

Феномен пиратских радија, најпре у Великој Британији, је упркос неетичности и непрофесионалности у емитовању програмског садржаја, занимљива појава јер је утицала на развој радија како у техничком, тако и у програмском смислу, развијајући вишеструке потенцијале и идентитет тог медија (према Scannell, 1991:205).

\section{3. МЕТОДОЛОГИЈА}

Како би се описао феномен пиратских радио-станица у Србији, у раду ће бити кориштене три истраживачке методе (према Kulenović, Slišković, $2008)^{2}$. Метода дескрипције је поступак једноставног описивања чињеница, процеса и предмета у друштву, те емпиријских потврђивања њихових односа и веза, али без научног тумачења и објашњавања. Овом методом биће описан начин настанка пиратских медија. Компаративна метода је поступак

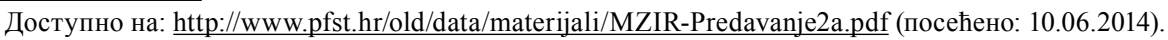


упоређивања истих или сродних чињеница, појава или процеса и односа, односно утврђивање њихове сличности и разлика. Овом методом биће упоређене пиратске станице с половине 20. века и оне које у 21. веку емитују програм ${ }^{3}$. Трећа метода, која се може веома корисно употребити у комбинацији са претходне две, јесте компилација која представља поступак преузимања туђих резултата научног или истраживачког рада. Овом методом, у актуелном друштвено-политичком контексту, биће приказана улога коју у радиодифузији Србије имају пиратске радио-станице.

\section{4. АНАЛИЗА И РЕЗУЛТАТИ}

\section{1. Пиратске радио-станице у Европи}

Историја пиратских станица дуга је готово колико и историја самог радија. Тридесетих година 20. века две радио-станице Нормандија и Луксембург почеле су да емитују програм врло различит од строго официјелног програма британског радија Би-Би-Cu, заснованог на начелу „информисати, образовати и забавити“. Топ листа и музика постале су прави хит, па је педесетих година 20. века Радио Луксембург био најпопуларнији електронски медиј у Европи. Године 1955. Луксембург је привукао око девет милиона слушалаца из Велике Британије, али само две године касније број слушалаца опао је за чак шест милиона јер радио-водитељи прелазе на нов медиј, односно телевизију - Aj-Tu-Bu (ITV). После 58 година, Радио Луксембург 1991. престао је да постоји ,јер није био у стању да конкурише великом броју независних радио-станица““ (према Zgrabljić Rotar, 2007:31; Шинглер, Виринга 2000: 32-43).

Станице без легалне дозволе појавиле су се у два основна облика. Први је унутар државних граница, а други у бродовима у међународним водама. „На произвољно одабраним таласима пиратске станице емитовале су програм углавном сумњивог квалитета у коме је доминирала музика и много реклама. У Великој Британији такве станице биле су истовремено и онај изазов који је натерао Би-Би-Си да се децентрализује и прихвати комерцијализацију дела радиодифузног система. И Шведска је проблем пиратерије решавала тако што је своје радио-програме отворила за популарну музику и тако пиратске радио-станице учинила сувишним. Данска се одлучила за директну репресивну акцију - њена поморска полиција једноставно је запленила бродове са којих је емитован пиратски радио програм, а посада тих бродова осуђена је на строге затворске казне. Француска, која је окружена франкофонским земљама, чије су комерцијалне радио-станице поред музичких хитова емитовале и рекламе намењене француском аудиторијуму - изабрала је трећи пут. Она је неколико таквих најпопуларнијих станица

\footnotetext{
У питању су два таласа настанка пирата у Србији - један почетком деведесетих година 20. века и други након завршетка конкурса за доделу фреквенција од 2008. до 2014.
} 
(на пример Paдиo Jypon 1 / Europe Nol) једноставно ставила под своју контролу тако што је на берзи купила контролни пакет њихових акција. У Грчкој је, на пример, главни мотив оснивања пиратских радија током седамдесетих година 20. века био жеља за отвореном комуникацијом и отпор војној хунти у тој земљи (1967-1974).

Други вид пиратства огледао се у покушају да се искористе извесне недоречености међународног права. Радио-станице монтиране су на пловне објекте, укотвљене на отвореном мору, изван територијалних вода земаља на које су усмеравале свој програм“ (Радојковић, Стојковић, 2009:65). Први прави пиратски радио Каролина (Radio Caroline) почео је да емитује програм 1964. са брода уз обалу Есекса (Енглеска) и у првој недељи преузео је трећину Би-Би-Сијевих слушалаца (слика 1).

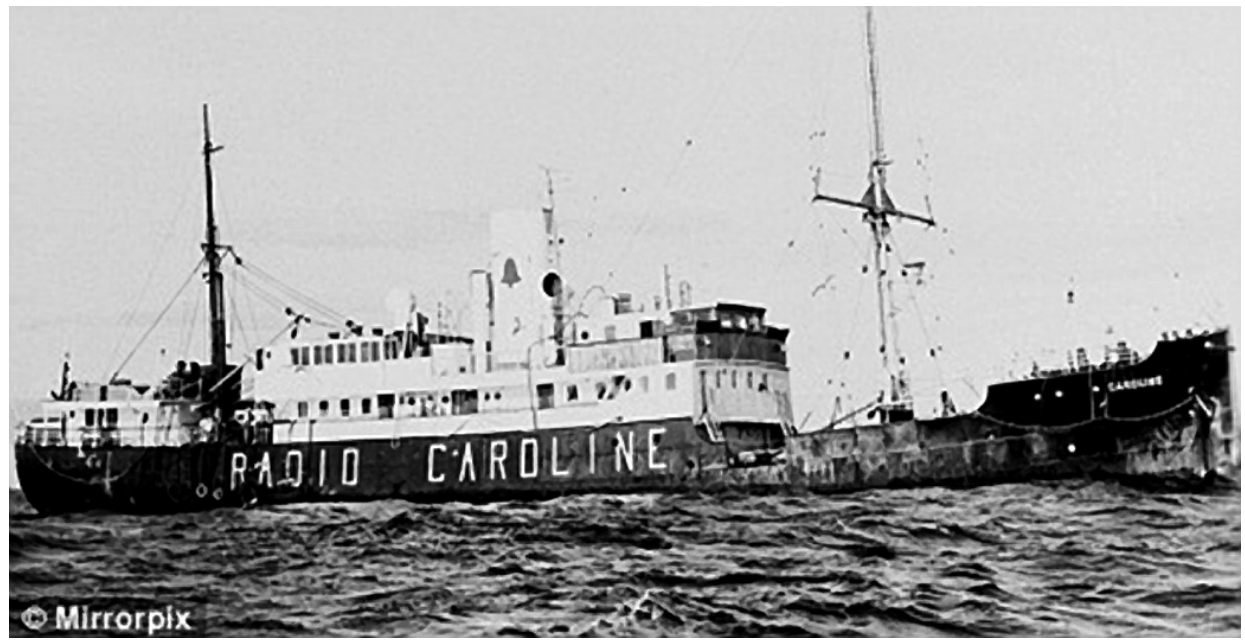

Извор фотографије: http://www.dailymail.co.uk/tvshowbiz/article-1158007/ My-stormy-life-aboard-boat-rocked-Britain---A-DJ-looks-pirate-radio-era.html (посећено: 10.06.2014).

У наредним годинама ницале су многе сличне радио-станице и ускоро их је било двадесетак са десетинама милиона слушалаца. Оснивач Радио Каролине био је млади музички импресарио из Лондона Ронан O' Рајли. Заљубљеници у радио кажу да оно што је Титаник међу бродовима, Сент Егзипери међу пилотима, а И-Тu (ET) међу ванземаљцима, то је Каролина међу радио-станицама, једна од медијских легенди 20. века. Радио Каролина основана је са циљем да помогне афирмацији младих уметника и музичких поп-састава, те је ускоро постала медиј који је разбио монопол британског радија ${ }^{4}$. Једном уредбом Владе у Лондону (Marine Offences Act), „пиратске станице проглашене су противзаконитим, што је Би-Би-Сuјy отворило простор за

http://www.radiocaroline.co.uk./index.html\#history.html (посећено: 10.06.2014). 
покретање четвртог, динамичнијег, младог програма. Тиме ипак није заустављен развој неслужбених пиратских станица““ (Зграбљић Ротар 2007:32). Пиратерија међу радио-станицама у већем делу европског континента у велиој мери је сузбијена крајем шездесетих година 20. века када је 1967. ступио на снагу Европски договор о превенцији емитовања изван начионане територије, који је усвојио Европски савет 22.1.1965. у Стразбуру (European Agreement for the Prevention of Broadcasts Transmitted from Outside National Territories ${ }^{5}$ ). „Држава на коју су усмераване емисије најчешће би интервенисала и укидала емитере који су, у суштини, деловали изван њеног регуларног информационо-комуникационог система. Пиратске радио-станице ометане су, уз прећутну сагласност осталих држава и Међународне комуникационе уније, без обзира на то што интервенција државе ван сопствених територијалних вода представља повреду међународног права. За разлику од првог појавног вида пиратских електронских медија, који је имао политичку и поготову културну димензију, други, екстериторијални вид пиратства увек је био мотивисан, пре свега, комерцијалним интересима“ (Радојковић, Стојковић, 2009: 65-66).

\section{2. Пиратске радио-станице у Србији}

\subsection{3. Оснивања приватних медија и пиратске радио-станице првог таласа}

Од првих вишестраначких избора у Србији 1990. до 2002, када је усвојен Закон о радиодифузији који је представљао основу за сређивање медијског хаоса, у етру Србије могло је да се прати преко 1.200 радијских програма. Односно, у просеку сваке седмице отварано је по две нове станице. Умножавање радијских и телевизијских станица, режим тадашњег председника Слободана Милошевића није спречавао, јер је стратегија произвођења неизвесности, привилегија и репресије учинила да знатан број електронских медија прихвати поданичко-привилегован статус (према Ђорић, 2002:5-9). Тако се због политичке осетљивости и потенцијалне моћи електронских медија делатност приватних медија регулише кроз неформалне аранжмане, коју су често резултат нагодбе политичара и приватника, односно бизнисмена (према Рабреновић и др. 2001:101-102).

Највећи број локалних радио-станица у Србији настаје од 1994. до 1998. када се њихов број пење на преко 500, од којих је око две трећине нелегалних. Влада Србије престала је да расписује конкурсе за фреквенције, а Савезна дирекција за радио-везе, стопирала је издавање привремених дозвола (према Пралица 2010:94). Новоуспостављено Савезно министарство за телекомуникације 1998. расписало је конкурс за привремено коришћење радијских

Документ доступан на: http://conventions.coe.int/Treaty/en/Treaties/Html/053.htm (посећено 10.06.2014). 
фреквенција. На том конкурсу привремене дозволе добиле су 174 радиостанице, док је поступак легализације настављен све до почетка бомбардовања НАТО-а 1999. Подаци Савезног министарства за телекомуникације из пролећа 2000. говоре да је програме са дозволом у том тренутку у Србији емитовало „око 500 радио и телевизијских станица“, док је готово 170 станица било у етру без икаквих дозвола (према Ђорић, 2002:30; Милетић, 2001:174-179).

У етру Србије на почетку 2000. било преко 610 радијских станица, док их је 10 година раније било само 63, што је пораст од преко 970\% у односу на 1990. Кулминација броја електронских медија у Србији догодила се крајем деведесетих година XX века, да би НАТО бомбардовање 1999. успорило, односно сасвим зауставило раст броја радио-станица.

Ни на једном месту не постоји званичан податак о томе која је прва пиратска радио станица емитовала програм на подручју Србије. Као што је већ речено, велики број приватних, комерцијалних медија радио је (полу)легално без дозвола за коришћење фреквенција, али су неке од станица држави редовно плаћале таксе за предајнике, што опет није била довољна гаранција колико ће дуго станица моћи да емитује програм. Почетак бомбардовања власт Слободана Милошевића искористила је за обрачун са непослушним медијима којима је привремено одузимала предајнике и практично онемогућила даљи рад (према Златковић 2001:9-13). На удару су се нашле оне станице које су биле критички настројене према тадашњој власти.

\subsection{4. Конкурентски програми првих пиратских радија у Србији}

И пре бомбардовања 1999. постало је очигледно како су, без обзира на сумњив квалитет и ниске професионалне стандарде већине нових приватних станица, па самим тим и пирата, њихови програми постали оштра конкуренција општинским радио-станицама са дугогодишњом традицијом. Разлози за то били су вишеструки. Таква радио-станица финансијски била је у знатној мери самоодржива и профитабилна иначе би ју власник затворио. Није имала велики број запослених (неколико новинара и техничара), а уз компјутерску технику била је у знатној предности над општинским станицама које су, углавном, радиле са застарелом опремом и много људи средњих година. Нове станице давале су предност младим људима који су желели да се креативно докажу и на модеран, урбан начин информишу околину звучном сликом која је била супротна оној коју су нудиле традиционалне $\mathrm{cma}^{6}$ нице. Уколико су приватне радио-станице имале информативни програм он је био другачији од онога што је јавности сервирано деценијама7. Млади

6 Мисли се на Радио Београд, Радио Нови Сад, као и бројне општинске радио-станице које су постојале више деценија.

7 На пример информативни програм Радија 021 био је од 1998. до 2008. слушанији од свих других радио-станица, укључујући и Радио Нови Сад и Радио Београд, на подручју градске заједнице 
новинари имали су другачији приступ проблему, креирали су оригиналне шпице и цинглове, кратке вести, контакт- програм. Међутим, било је и оних радија, такозваних иубокс станица, чији је програм био доминантно забавног карактера, са преко 90\% музичког садржаја и то турбофолк музике. Упркос таквом тривијалном концепту и непостојању стриктне програмске шеме и те станице биле су конкуренција општинским. Опште је познато да су иубокс станице могле програм да емитују из једне собе, са једним водитељом, једним компјутером и много музичких нумера које су нелегално преузимане са интернета. Такве станице биле су у могућности да веома лако пласирају забавно-сервисне програме са малим огласима, обиљем реклама, музичких жеља и наградних игара, као и контакт-емисијама, односно укључењима слушалаца.

\subsection{5. Независна регулаторна тела и пиратске радио-станице другог таласа}

Чињеница је и да демократска власт после свргавања режима Слободана Милошевића 5. окробра 2000. није одмах започела реформу медијског сектора. Нова власт практично је прогласила општу амнестију, а сви емитери остављени су у етру без обзира на њихово понашање и програмски садржај (према Серечеш, Исаков, 2010:60). Јавност, али и медији од 2006. до 2009. били су веома заинтересовани за праћење реформе медијског сектора. Тој реформи непосредно је претходило доношење медијских закона ${ }^{8}$ и формирање Републичке радиодифузне агенције $(P P A)$ и Републичке агенције за телекомуникације ${ }^{9}(P A T E Л)$, чији је циљ био увођење реда у сферу рада електронских медија у Републици Србији. То је значило почетак рада два јавна радиодифузна сервиса Србије и Војводине, као и расписивање конкурса за доделу дозвола за емитовање програма на националном, покрајинском, регионалном и локалном нивоу, као и почетак (никада до краја завршеног) процеса приватизације радио-станица локалне/регионалне заједнице (према Пралица, 2010:89).

Након завршетка конкурса за доделу фреквенција (2006-2008) ${ }^{10}$, један део радио-станица који није добио дозволу за рад наставио је да емитује програм. Те станице, практично можемо сматрати првим, правим пиратским медијима у Србији. За разлику од пиратских радио-станица првог таласа, чија је

Новог Сада. Године 2008. Радио 021 добио је од Републичке радиодифузне агенције (РРА) дозволу за коришћење фреквенције на подручју града Новог Сада на осам година, па се самим тим више не може сматрати неком врстом пиратског медија.

8 Закон о радиодифузији из 2002, Закон о јавном информисању из 2003. и Закон о телекомуникацијама из 2003.

9 Након ступања на снагу Закона о електронским комуникацијама 2010, односно 2013, РАТЕЛ је преименован у Републичку агенцију за електронске комуникације.

10 PРA је 2010. расписала конкурс за доделу још 14 фреквенција за локално емитовање на подручју Војводине. 
мисија описана у одељку 4.2.4, пиратски медији другог таласа постали су нелојална конкуренција свим оним медијима који су учестовали на конкурсу, добили фреквенције и сада месечно држави плаћају накнаде за коришћење тих фреквенција. Пирати су били ослобођени тих обавеза, а програм су наставили да емитују и угрожавају легалне емитере.

„Објављивањем Јавног саопштења РРА И РАТЕЛ-а у Политиичи 31. јула 2008. којим се којим се позивају сва правна и физичка лица да прекину незаконито емитовање радијског и ТВ програма, у Србији је први пут почела организована борбра против електронских медија који нелегално емитују програм“" (Јокановић, 2009: 8-9). Упркос томе што су из државних агенција тврдили да они редовно спроводе контроле ${ }^{11}$, број пиратских медија, нарочито у Војводини био је релативно константан. Према подацима РАТЕЛ-а из 2011. у Србији је регистровано 45 радио-пирата који емитују програм, у 2012. било их је 36, а у јануару 2014. 27. Детаљније у табели 1:

Табела 1.

\begin{tabular}{|l|c|c|}
\hline број пиратских медија & период & извор \\
\hline 45 радио-станица & септембар 2011 & РАТЕЛ $^{1}$ \\
\hline 36 радио-станица на 47 фреквенција & јул 2012. & РАТЕЛ $^{2}$ \\
\hline 27 радио-станица на 37 фреквенција & јануар 2014. & РАТЕЛ $^{3}$ \\
\hline
\end{tabular}

${ }^{1} \mathrm{http} / / /$ www.ratel.rs/информације/новости.82.html?article_id=1154 (посећено 10.06.2014).

${ }^{2} \mathrm{http}: / /$ www.ratel.rs/informacije/novosti.234.html?article_id=1257 (посећено 10.06.2014).

${ }^{3} \mathrm{http}: / /$ www.ratel.

Легални емитери више пута су упозоравали да имају многоструке штете од пиратских медија. На округлом столу ${ }^{12}$ о пиратским радио-станицама, одржаном у Новом Саду 29.05.2009, представници емитера из Новог Сада, Вршца, Алибунара, Зрењанина, Суботице, Сомбора, Кањиже, Сенте и других војвођанских градова казали су да су држава и регулаторне агенције обавезне да обезбеде легалним емитерима нормално пословање и да угасе пиратске емитере. На том скупу представљена је и анализа Додела дозвола за емитовање и пиратски радио, чији је аутор Синиша Исаков указао да би процедура гашења пирата морала много брже да се одвија. И Удружење радио-станица РАБ Србија критиковало је у априлу 2013. регулаторна тела да недовољно раде на сузбијању пиратских медија. То удружење (легалних) комерцијалних радио-станица навело да је да су чланице РАБ Србије „у више наврата РРА и РАТЕЛ упознавали са штетним ефектима нелегалног емито-

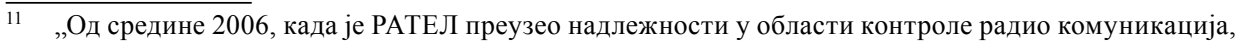
највише је рађено у домену радиодифузије где су откривани нелегални емитери и прекидан рад илегалних тзв. пиратских радио-станица““ (Јокановић, Борић, 2009:233).

12 Доступно на: http://www.rtv.rs/sr lat/drustvo/legalni-emiteri-se-udruzuju-traze-gasenje-pirata 128753. html (посећено: 10.06.2014). 
вања програма, али је деловање ове две државне институције спорадично и недовољно ефектно"'13.

Држава је формално прокламовала борбу против нелегалних емитера и то у Стратегији развоја система јавног информисања у Републици Србији до 2016. године (која је на снази од 2011). Ипак, у том документу само се на два места помињу пиратски медији - када се констатује да постоје и да је држава дужна да их сузбије. Дакле, пиратски медији допринели су „неоправдано великом броју медија" у Србији и 1.07.2011, према подацима РАТЕЛ-а, било их је 47, док је ,у претходном периоду затворено 160 радио и телевизијских станица које су без дозволе емитовале програм". Са тим у вези додаје се и да je ,у надлежном министарству, у сектору за електронске комуникације, уведена инспекцијска служба од које се очекује да реши настали проблем”. Други пут појам пирата помиње се када се констатује да је „Република Србија обавезна да сузбија пиратерију, штити ауторска и сродна права..."14

Међутим, ни три године касније, није се много тога урадило у овој области. Заменик начелника Одељења Министарства унутрашњих послова за високотехнолошки криминал Драган Јовановић, на округлом столу ${ }^{15}$ о пиратерију, одржаном у Београду 25. 03.2014, изјавио је да се број пиратских емитера не смањује, јер када то одељење успе да затвори неке, одмах са радом крећу друге. Милош Стојковић из правног тима Асоцијащије независних електронских медија (AHEM) је том приликом рекао да је кажњавање пиратских станица немогуће јер законска регулатива има „дефект“ и додао да ти случјеви кад стигну до суда углавном застаре, јер се власници пиратских станица не одазивају на рочишта, а полиција не жели да их приводи.

\subsection{6. Прочедура гашења пиратских радио-станищฺа}

Републичка агенција за електронске комуникације (РАТЕЛ) једина је, према важећим прописима, надлежна да врши контролу коришћења радиофреквенцијског спектра, али не и да санкционише рад пиратских радиостаница. РАТЕЛ податке о нелегалним емитерима доставља Републичкој радиодифузној агенцији (РРА) и инспекцији Министарства телекомуникација који су овлашћени да врше прекидање нелегалног рада.

Као прву меру против пирата, РАТЕЛ издаје Решење о престанку рада. Уколико власник нелегалне станице не прекине емитовање програма, РАТЕЛ доноси Закључак о принудном извршењу мере печаћењем предајника, уз покретање прекршајног поступка против власника тог медија. Процедуру

Доступно на: http://www.rabsrbija.com/about/vesti-za-medije/263/RAB+Srbija+protiv+piratskih+radi o+stanica, + neregularnih + mre\% $\% 5 \% \mathrm{BEa}+\mathrm{i}+$ nedozvoljene + medijske+koncentracije.html (посећено: 10.06.2014).

14 Доступно на: http://www.mc.rs/upload/documents/Medijska_politika/092811_strategija_razvoja_ sistema_javnog_informisanja00516 cyr.pdf (посећено 10.06.2014).

15 Доступно на: $\underline{\text { http://www.uns.org.rs/desk/media-news/23522/u-srbiji-50-ilegalnih-radio-stanica.html }}$ (посећено: 10.06.2014). 
гашења пирата додатно компликује Закон о електронским комуникацијама и Закон о управном поступку који као казнену меру не предвиђају одузимање предајника. Тако се дешавало да, након печаћења просторије где се налази предајник, власник пирата поново покрене програм.

Друго регулаторно тело које учествује у процедури уклањања пирата из етра, Републичка радиодифузна агенција (РРА), својевремено је донело Правилник о извршеюу којим су Савету РРА дата додатна овлашћења. На основу тога за кратко време „угашени су сви нелегални емитери на подручју Београда. Нажалост, истичи у Савету РРА, Уставни суд Србије тај Правилник ставио је ван снаге“ (Серенчеш, Исаков 2010:67-68). Као последица те одлуке, број пирата у другим деловима земље, с акцентом на Војводину, није се драстичније смањио. Савет РРА је након тога предложио да се у Кривичном законику директно санкционише радио-пиратерија, али та иницијатива није прошла. Како би делимично покушала да утиче на смањење броја нелегалних емитера у Војводини, РРА је 2009. у Новом Саду отворила Одељење Службе за надзор и анализу.

Иако су подаци РАТЕЛ-а говорили да се перманентно (на нивоу државе) смањује број нелегалних емитера, у Војводини је и даље радио највећи број пирата. Један од разлога за то јесте географске природе - односно планина Фрушка гора на коју пирати постављају нелегалне предајнике и одакле своје сигнале углавном усмеравају ка главном граду Покрајине. Последица тога јесте да је од 27 маркираних пирата чак 18 у Војводини, од којих се осам станица чује на подручју Новог Сада где омета легалне емитере којих има $14 .{ }^{16}$

Други разлог јесте политичке природе. У РАТЕЛ-у, као и у Министарству за трговину и телекомуникације потврдили су у јануару 2014. да су за послове прекидања рада нелегалних станица на територији Војводине надлежни покрајински инспекцијски органи. „С друге стране, у Покрајинском секретеријату за привреду су казали да они немају запосленог инспектора за електронске комуникације правдајући се да је у току поступак 'поверавања надлежности', па ће инспектора или више њих запослити тек када добију за то дозволу“" од Министарства телекомуникација (Крајновић, 2014, пара. 3,4). Заменик председника Савета РРА Горан Караџић изјавио је на консултацијама $^{17}$ са медијима у Новом Саду 12.02.2014. да у Војводини нема ниједног инспектора за телекомуникације, због чега је ова покрајина постала „легло пиратерије“. Он је казао да је проблем у томе што још није примењен Закон о надлежностима Војводине, који предвиђа да Аутономна Покрајина има

\footnotetext{
16 Према подацима Европске радио-мапе (The European Radio Map), у Новом Саду доступни су радиопрограми на око 50 фреквенција од 87,5 до $108 \mathrm{MHz}$. Доступно на: http://radiomap.eu/rs/novi-sad (посећено: 10.06.2014). Иако се на подручју главног града Војводине чује знатно већи број станица (укључујући и оне са дозволом за националне фреквенције), међу 14 радија убрајају се они којима jе седиште у Новом Саду. Подаци доступни на: http://www.rra.org.rs/pages/search_permits/latinica (посећено: 10.06.2014).

17 Доступно на: http://www.rts.rs/page/stories/sr/story/2208/Izbori+2014/1519799/RRA\%3A+Poziv+med ijima + da + po\% $\mathrm{C} 5 \%$ Altuju+zakon+.html (посећено: 10.06.2014).
} 
ингеренције у надзору телекомуникација, али још нема ниједног инспектоpa, док их у другим деловима Републике има пет. И чланом 132 Закона о електронским комуникацијама ${ }^{18}$ прописано је да инспекцијски надзор на територији Војводине врши Аутономна Покрајина преко својих органа, као поверене послове.

Пиратско емитовање програма квалификује као „неовлашћено бављење одређеном делатношћу, односно неовлашћено искоришћавање ауторског дела, или предмета сродног права, и не припада тежим облицима привредног криминала. За прво је предвиђена новчана, или казна затвора до две године, а у другом случају затворска казна до пет година“ (Прерадовић, 2012, пара. 4).

\subsection{7. Пиратске радио-станице као претња}

Нелегални емитери, упркос томе што њихов број у односу на легалне није значајан, представљају веома велику претњу свим легалним медијима, првенствено на подручју где су узурпирали фреквенције. Према подацима ${ }^{19}$ из јуна 2014. у Србији, са дозволом РРА 327 станица емитује своје програме. Од тога пет имају националне дозволе, две покрајинске, 48 регионалних и 272 локалних. Број станица ${ }^{20}$ које су нелегално у етру је 27 (табела 2), што представља око осам процената од укупног броја радио-станица које се могу слушати широм Србије (графикон 1):

Табела 2.

\begin{tabular}{|l|c|}
\hline \multicolumn{1}{|c|}{ назив пиратске радио-станице и седиште } & $\begin{array}{c}\text { запоседнута фреквенција } \\
\text { емитовања (MHz) }\end{array}$ \\
\hline Радио Култ, Пожаревац & 102,7 \\
\hline Интернет Радио, Руски Крстур & 96,9 \\
\hline Радио Гром, Зрењанин & 99,8 \\
\hline Радио Ваки, Земун & 103,7 \\
\hline Радио Ибис, Меленци & 96,7 \\
\hline Радио Грмеч, Нови Сад & 96,9 \\
\hline Радио Зец, Нови Сад & 104,8 \\
\hline Радио Антена, Нови Сад & 104,2 \\
\hline Радио Гес, Нови Сад & 105,6 \\
\hline Радио Рудно, Краљево & 88,9 \\
\hline
\end{tabular}

18 Доступно на: http://www.paragraf.rs/propisi/zakon_o elektronskim_komunikacijama.html (посећено: 10.06.2014).

19 Доступно на: http://www.rra.org.rs/pages/search_permits/latinica (посећено: 10.06.2014).

20 Подаци из јануара 2014. Доступно на: http://www.ratel.rs/\%D0\%B8\%D0\%BD\%D1\%84\%D0\%BE\%D1\%80\%D0\%BC\%D0\%B0\%D1\%86\%D0\%B8\%D1\%98\%D0\%B5/\%D0\%BD\%D0\%BE\%D0\%B2\%D0\%BE\%D1\%81\%D1\%82\%D0\%B8.82.html?article id=1455 (посећено: 10.06.2014). 


\begin{tabular}{|c|c|}
\hline Радио Српска Крајина, Нови Сад & 99,1 \\
\hline Радио без идентификације, Фрушка гора & 102,9 \\
\hline Радио Завичај, Беочин & 102,2 \\
\hline Радио без идентификације, Фрушка гора & 103,5 \\
\hline Радио Младост, Апатин & 101,0 \\
\hline Радио Д-65, Дероње & 100,5 \\
\hline Радио Сутон, Кула & 91,7 \\
\hline Радио Падина, Падина & 88.4 \\
\hline Радио Антена, Шљивова (Крупањ) & 102,0 \\
\hline Радио Зене, Чантавир & 90,9 \\
\hline Радио Енигма, Пријепоље & 104,3 \\
\hline Радио Завичај Плус, Краљево & 104,7 \\
\hline Радио Скај, Врање & 107,5 \\
\hline Радио 013, Пландиште & 90,9 \\
\hline Радио Јесењин, Нови Сад & 104,5 \\
\hline Радио Бубоња, Љиг & 99,5 \\
\hline \multicolumn{2}{|l|}{ Радио Балкан реемитује програм радија Фокус } \\
\hline Пожаревац & 91,6 \\
\hline Врање & 105,6 \\
\hline Крушевац & 94,8 \\
\hline Вршац & 93,0 \\
\hline Поповица & 107,0 \\
\hline Београд & 97,9 \\
\hline Нови Пазар & 96,7 \\
\hline Цер & 92,2 \\
\hline Селичевица & 104,1 \\
\hline Зрењанин & 88,7 \\
\hline
\end{tabular}

радио станице које емитују програм у СРБ

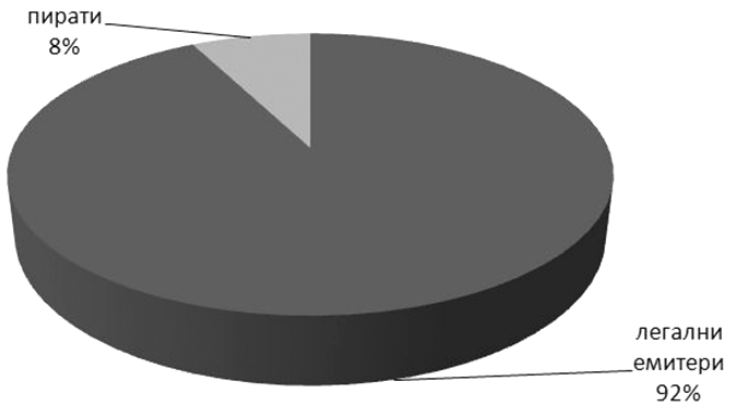

Графикон 1. 
Емитовање пиратских радијских програма штетно је из више разлога:

1) Могу да угрозе рад виталних служби које се баве безбедношћу авиосаобраћаја, затим рад полиције, војске, ватрогасаца, односно свих оних служби које користе легалне фреквенције;

2) Нелагалним запоседањем/узурпацијом фреквенције угрожава се пријем програма легалних емитера, што има за последицу пад слушаности, а самим тим и смањен приход од маркетинга;

3) Слушаоци легалних медија остају ускраћени за квалитетан звук (мешају се фреквенције);

4) Нелегални емитери представљају општу опасност за друштво - никоме не полажу рачуне. Њихове програме нико не контролише, могу да угрозе јавни ред и мир, емитују говор мржње, нелегалне игре на срећу и слично (према Јокановић, 2009: 8-9);

5) Емитују домаћу и страну музику без плаћања ауторских права;

6) Власници пирата не плаћају држави никакве таксе па могу да понуде повољније услове оглашивачима (нелојална конкуренција).

Већина пиратских радио-станица свој програм рекламира и преко интернета, односно има могућност слушања и преко интернета. На тим сајтовима, који углавном нису интерактивни, могу се видети само штури подаци о називу медија, фреквенцији, начину слања СМС порука за музичке жеље и ценама тих порука код различитих оператера. На неким сајтовима, попут Радија Завичај $n л y c^{21}$ u Радио Јесенина ${ }^{22}$, на пример, могу се пронаћи и подаци о власнику медија, сликама водитеља, па чак и чланова породице (фотографија 2). Углав-

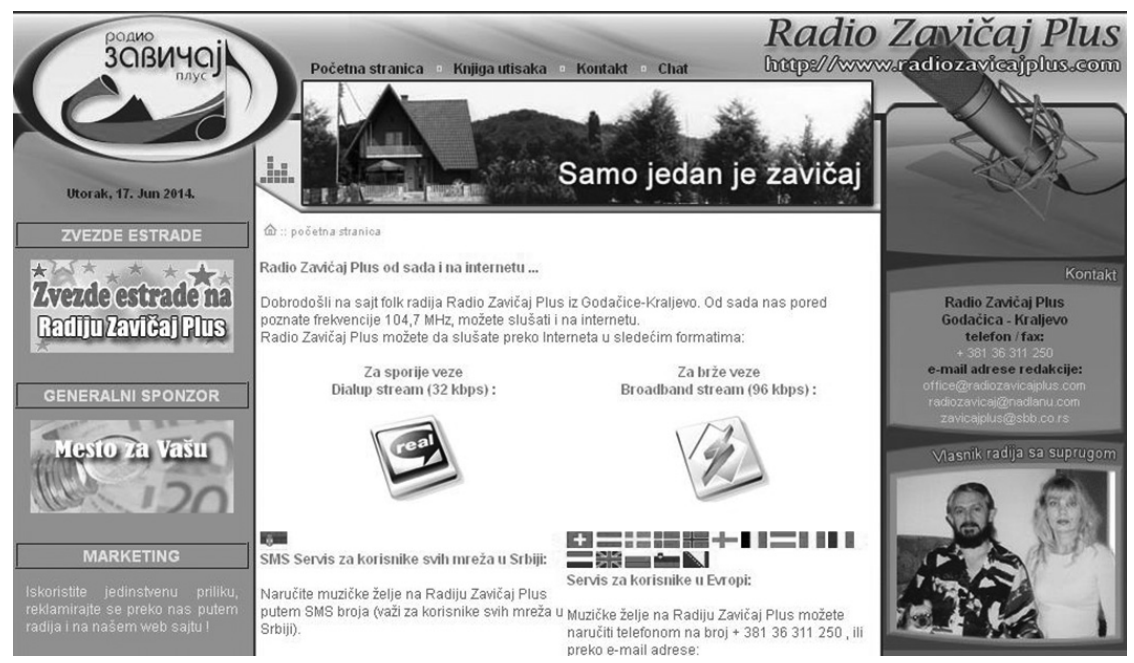

Фотографија 2 - изглед почетне странице пиратске радио-станице Завичај плус из Краљева.

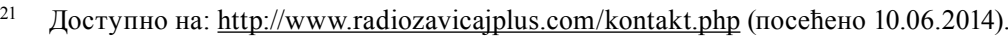

22 Доступно: http://jesenjinradio.webs.com/jesenjin-tim (посећено 10.06.2014). 
ном недостају подаци о адреси редакције, фиксним телефонима и именима главних и одговорних уредника. Неке радио-станице, попут две које емитују програм са Фрушке горе (видети табелу 2), немају чак ни називе.

\section{5. ЗАКЉУЧНЕ НАПОМЕНЕ}

Радио-пиратерија, као сегмент у радиодифузији друге половине 20. века, одржао се до данас, али у другачијим околностима. „За нас је то занимљив феномен и зато јер показује како се радио у различитим земљама различито развијао с обзиром на то какво је друштвено-политичко окружење“ (Zgrabljić Rotar, 2007: 33).

Једина сличност између првих пиратских медија у Великој Британији, шездесетих година 20. века, и оних данашњих у Србији јесте нелегалан начин емитовања програма. Мотиви оснивања само су једним делом слични. Британски пирати оснивани су, између осталог, са циљем да се разбије медијски монопол и традиционализам Би-Би-Сија. Српски пирати, из такозваног првог таласа, оснивани су, углавном како би се успоставила равнотежа - противтежа такозваним прорежимским медијима које су током деведесетих година предводили Радио Београд и Радио Нови Сад. Разлоге оснивања актуелних пирата, из такозваног другог таласа треба тражити искључиво у економском интересу.

Иако постоји општи консензус у друштву да је било који вид пиратерије, па и радијске, врло штетан за државу и њене грађане уопште, и да је Cmpaтегијом развоја система јавног информисањ а Републици Србији до 2016. године. прокламована борба против пиратерије, резултати те борбе нису задовољавајући. На то најчешће указују легални емитери, као и медијска и новинарска удружења када протестују што ни после више година од леганог уређења етра Србије и доделе фреквенција (2006-2008) и даље одређен број медија емитује програм без дозволе и у периоду економске кризе отежава и те како комплексно функсионисање емитера који уредно држави плаћају дажбине.

Чињеница је да је број пиратских радио-станица у Србији у односу на број легалних емитера релативно занемарљив и износи свега осам процената, њихов опстанак у етру и концентрација на одређена подручја прети да угаси легалне радио-станице. Иако надлежне регулаторне агенције РАТЕЛ и РРА покушавају да сузбију пиратеске медије, блага казнена политика и до краја недефинисане надлежности између Републике и Покрајине довеле су до тога да у 2014. у Новом Саду, као другом по величини граду у земљи, $36 \%$ етра заузимају пиратске радио-станице, што је недопустиво. Такође је забрињавајуће што се, према свему ономе што се навелу у овом раду, тај проблем још неко време неће решити. 
Dejan Pralica

\title{
PIRATE RADIO IN SERBIA
}

\begin{abstract}
SUMMARY
The aim of this paper is to present the problem of pirate radio stations in Serbia, especially in the Autonomous Province of Vojvodina. The development of pirate electronic media in Europe began in the mid $20^{\text {th }}$ century, when some illegal stations were the broadcasting avant-garde of the time and even competitors which forced the official radio stations to improve their program. More than half a century later, the role of pirate media has partly changed. They are still rivals to the radio stations which applied for and received frequencies from the state officials, and their program deteriorates the quality of the program on the air. Although the number of media which illegally use radio frequencies is decreasing, they are still a big problem. This paper will give an account of the procedures the official (state) regulatory agencies use to decrease the number of illegal radio stations in Serbia.
\end{abstract}

Keywords: pirate, radio station, royalties, RRA, RATEL.

\section{ЛИТЕРАТУРА}

Dictionary of Media Studies (2006). London: A\&C Black.

Ђорић, Слободан (2002). Бела књига о радиодифузији 1990-2000. Београд: Спектар. Златковић, Јованка (2001). Узводно од 021. Нови Сад: Радиодифузно предузеће 021.

Јокановић, Душан (2009). Пиратске радиодифузне станице у Србији. Линк-часопис за професионалие у медијима, бр. 83, год. 9, 8-9.

Јокановић, Душан; Борић, Александар (2009). Улога инспекција у управљању РФ спектром. У: 27. Симпозијум о новим технологијама и поштанском и телекомуникационом саобраћају - ПосТел 2009. - зборник радова (стр. 227-234). Београд: Саобраћајни факултет. Доступно на: http://postel.sf.bg.ac.rs/downloads/simpozijumi/POSTEL2009/ RADOVI\%20PDF/Telekomunikacioni $\% 20$ saobracaj, $\% 20$ mreze $\% 20 \mathrm{i} \% 20$ servisi $/ 2 . \% 20$ D.\%20Jokanovic,\%20A.\%20Boric.pdf

Крајновић, Слободан (21.1.2014). Пирате који харају Новим Садом и Војводином нема ко да затвара. Радио 021. Доступно на: http://www.021.rs/Novi-Sad/Vesti/Pirate-koji-harajuNovim-Sadom-i-Vojvodinom-nema-ko-da-zatvara.html (посећено: 10.06.2014).

Kulenović, Zlatan; Slišković, Merica (2008). Metodologija znanstvenoistraživačkog rada. Split: Pomorski fakultet u Splitu. Dostupno na:

http://www.pfst.hr/old/data/materijali/MZIR-Predavanje2a.pdf (посећено: 10.06.2014).

Милетић, Мирко (2001). Масмедији у вртлогу промена: друштвене промене и масовно комуницирање у Србији у последюој деценији 20. века. Београд: Заједница радио-телевизијских станица Србије.

Николић, Данило Л. (2010). Медијско право. Београд: Службени гласник.

Пралица, Дејан (2010). Анализа медијског дискурса одабраних штампаних медија о трансформацији војвођанских радио-станица. ЦМ-часопис за управљање комуниичирањем, бр. 16, год. 5, 89-103.

Пралица, Дејан (2010). Локални радио у вишејезичној средини: пример Аутономна Покрајина Војводина. Београд: Факултет политичких наука (необјављена докторска дисертација). 
Прерадовић, Љиљана (5.11. 2012). Илегалне радио-станице ометају и авионе. Вечење новости. Доступно на: http://www.novosti.rs/vesti/srbija.73.html:404487-Ilegalne-radiostanice-ometaju-i-avione (посећено 10.06.2014).

Рабреновић, Александра; Кремењак, Слободан; Живковић, Милош и Ритлер, Роберт (2001). Право радиодифузних предузећа. Београд: Центар за унапређивање правних студија.

Радојковић, Мирољуб; Стојковић, Бранимир (2009). Информационо-комуникациони системи (2. издање). Београд: Клио.

Речник српскога језика (2007). Нови Сад: Матица српска.

Серенчеш, Жужана; Исаков, Синиша (2010). Војвођански медији - политички компромис или професионално извештавање. Нови Сад: Независно друштво новинара Војводине.

Scannell, Paddy (1991). Broadcast Talk. London: SAGE Publications.

Шинглер, Мартин; Виринга, Синди (2000). Радио. Београд: Клио.

Zgrabljić Rotar, Nada (2007). Radio mit i informacija, dijalog i demokracija. Zagreb: Golden marketing - Tehnička knjiga.

\section{ИНТЕРНЕТ ИЗВОРИ:}

Daily Mail. http://www.dailymail.co.uk/tvshowbiz/article-1158007/My-stormy-life-aboardboat-rocked-Britain---A-DJ-looks-pirate-radio-era.html (посећено: 10.06.2014).

European Agreement for the Prevention of Broadcasts Transmitted from Outside National Territories. http://conventions.coe.int/Treaty/en/Treaties/Html/053.htm (посећено: 10.06.2014).

Radio Caroline. http://www.radiocaroline.co.uk./index.html\#history.html (посећено: 10.06.2014).

РАБ Србија. http://www.rabsrbija.com/about/vesti-za-medije/263/RAB+Srbija+protiv+pirat $\underline{\text { skih }+ \text { radio }+ \text { stanica },+ \text { neregularnih }+ \text { mre } \% \mathrm{C} 5 \% \mathrm{BEa}+\mathrm{i}+\text { nedozvoljene }+ \text { medijske }+ \text { koncentr }}$ acije.html (посећено: 10.06.2014).

Радио Јесењин. http://jesenjinradio.webs.com/jesenjin-tim (посећено: 10.06.2014).

Радио-телевизија Војводине. http://www.rtv.rs/sr lat/drustvo/legalni-emiteri-se-udruzujutraze-gasenje-pirata 128753.html (посећено: 10.06.2014).

Радио-телевизија Србије. http://www.rts.rs/page/stories/sr/story/2208/Izbori+2014/1519799/ RRA\%3A+Poziv+medijima+da+po\%C5\%Altuju+zakon+.html (посећено: 10.06.2014).

Републичка агенција за електронске комуникащије (РАТЕЛ). http://www.ratel.rs/информације/новости.82.html?article id=1154; http://www.ratel.rs/informacije/novosti.234. html?article id=1257; http://www.ratel.rs/\%D0\%B8\%D0\%BD\%D1\%84\%D0\%BE\%D1\% 80\%D0\%BC\%D0\%B0\%D1\%86\%D0\%B8\%D1\%98\%D0\%B5/\%D0\%BD\%D0\%BE\%D0\% B2\%D0\%BE\%D1\%81\%D1\%82\%D0\%B8.82.html?article id=1455 (посећено: 10.06.2014).

Републичка радиодифузна агенција. http://www.rra.org.rs/pages/search_permits/latinica (посећено: 10.06.2014).

Стратегији развоја система јавног информисањ у Републици Србији до 2016. године. http://www.mc.rs/upload/documents/Medijska_politika/092811_strategija_razvoja sistema javnog informisanja00516_cyr.pdf (посећено: 10.06.2014).

The European Radio Map. http://radiomap.eu/rs/novi-sad (посећено: 10.06.2014).

Удружење новинара Србије. http://www.uns.org.rs/desk/media-news/23522/ u-srbiji-50ilegalnih-radio-stanica.html (посећено: 10.06.2014). 